\title{
Crystal structure of 1-nonylpyridazin-1-ium iodide, $\mathrm{C}_{13} \mathrm{H}_{23} \mathrm{~N}_{2} \mathrm{I}$
}

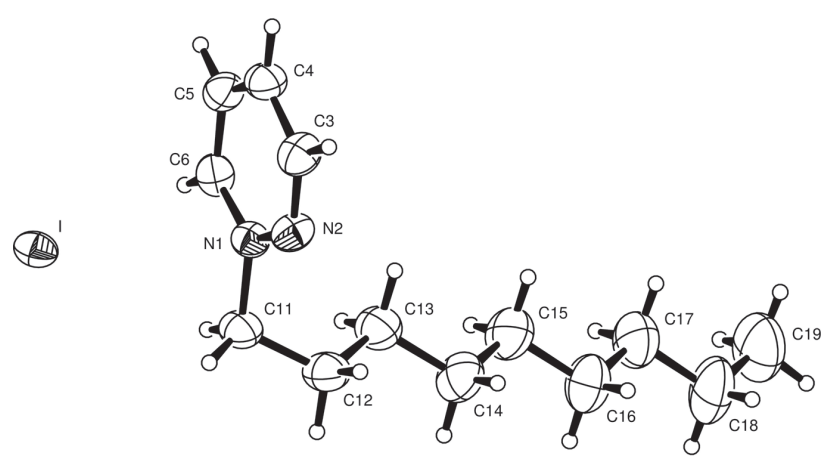

https://doi.org/10.1515/ncrs-2019-0024

Received January 8, 2019; accepted March 6, 2019; available online May 17, 2019

\section{Abstract \\ $\mathrm{C}_{13} \mathrm{H}_{23} \mathrm{~N}_{2} \mathrm{I}, \quad$ triclinic, $P \overline{1} \quad$ (no. 2), $a=5.6693$ (3) $\AA$, $b=8.9457(4) \AA, \quad c=16.2919(7) \AA, \quad \alpha=83.341(4)^{\circ}$, $\beta=89.534(4)^{\circ}, \quad \gamma=82.491(4)^{\circ}, \quad V=813.63(7) \AA^{3}, \quad Z=2$, $R_{\mathrm{gt}}(F)=0.0446, w R_{\text {ref }}\left(F^{2}\right)=0.0873, T=295(2) \mathrm{K}$.}

CCDC no.: 1885499

The molecular structure is shown in the figure. Table 1 contains crystallographic data and Table 2 contains the list of the atoms including atomic coordinates and displacement parameters.

\section{Source of material}

All chemicals were used without further purification. The title ionic liquid was prepared by a method reported earlier $[5,6]$. To a solution of pyridazine $(1.00 \mathrm{~g}, 12.5 \mathrm{mmol}$ in

*Corresponding authors: Musa A. Said and Mouslim Messali, Chemistry Department, Taibah University, PO Box 30002, Code 14177, Al-Madinah Al-Munawarah, Kingdom of Saudi Arabia, e-mail: musasaid04@gmail.com,musa_said04@yahoo.co.uk (M. A. Said); aboutasnim@yahoo.fr (M. Messali); and David L. Hughes, School of Chemistry, University of East Anglia, Norwich, NR4 7TJ, United Kingdom, e-mail: d.l.hughes@uea.ac.uk

Saud M. Almutairi: King Abdulaziz City for Science and Technology, Riyadh 11442, PO Box 6086, Kingdom of Saudi Arabia

Mohamed Reda Aouad: Chemistry Department, Taibah University, PO Box 30002, Code 14177, Al-Madinah Al-Munawarah, Kingdom of Saudi Arabia

๑ Open Access. ๑ 2019 Musa A. Said et al., published by De Gruyter. (c) BY Public License.
Table 1: Data collection and handling.

\begin{tabular}{ll}
\hline Crystal: & Yellow prism \\
Size: & $0.22 \times 0.06 \times 0.04 \mathrm{~mm}$ \\
Wavelength: & Mo $K \alpha$ radiation $(0.71073 \AA)$ \\
$\mu:$ & $1.95 \mathrm{~mm}^{-1}$ \\
Diffractometer, scan mode: & Oxford Diffraction Xcalibur-3 \\
& Sapphire-3, $\varphi$ and $\omega$ \\
$\theta_{\text {max }}$, completeness: & $25.0^{\circ},>99 \%$ \\
$N(h k l)_{\text {measured }}, N(h k l)_{\text {unique }}, R_{\text {int }}:$ & $10743,2866,0.059$ \\
Criterion for $I_{\text {obs }}, N(h k l)_{\text {gt }}:$ & $I_{\text {obs }}>2 \sigma\left(I_{\text {obs }}\right), 2345$ \\
$N($ param $)$ refined: & 145 \\
Programs: & CrysAlis \\
& WinG $[1]$, SHELX $[2,3]$, \\
&
\end{tabular}

$10 \mathrm{~mL}$ of toluene) was added dropwise 1-iodononane (3.18 g, $12.5 \mathrm{mmol}$ ) and the mixture was placed in a closed container and exposed to irradiation for $5 \mathrm{~h}$ at room temperature using a sonication bath. Completion of the reaction was marked by the precipitation of a solid from the initially clear and homogenous mixture in toluene. The pyridazinium-based ionic liquid was isolated by filtration and washed three times with ethyl acetate to remove any unreacted starting materials and solvent. Finally the 1-nonylpyridazin-1-ium iodide was dried at a reduced pressure to remove all volatile organic compounds. (Yield 75\%, yellow powder, m.p. 94-95 ${ }^{\circ} \mathrm{C}$ ). Crystals were obtained from a mixture of dichloromethane and $n$-hexane (1:2). Elemental analysis: Anal. Calc. For $\mathrm{C}_{13} \mathrm{H}_{23} \mathrm{IN}_{2}$ : C, 46.72\%; H, 6.94\%; N, 8.38\%; Found: C, 46.80\%; H, 6.99\%; $\mathrm{N}, 8.32 \% .{ }^{1} \mathrm{H}-\mathrm{NMR}$ (DMSO, $\left.400 \mathrm{MHz}\right): \delta$ [p.p.m.] $=0.85(\mathrm{t}, 3 \mathrm{H})$, $1.29(\mathrm{~m}, 12 \mathrm{H}), 1.99$ (quin, 2H), $4.82(\mathrm{t}, 2 \mathrm{H}), 8.63(\mathrm{t}, 1 \mathrm{H}), 8.76$ (t, 1H), $9.65(\mathrm{~d}, 1 \mathrm{H}), 9.99(\mathrm{~d}, 1 \mathrm{H}) ;{ }^{13} \mathrm{C}-\mathrm{NMR}$ (DMSO, $\left.100 \mathrm{MHz}\right)$ : $\delta$ [p.p.m.] $=14.1\left(\mathrm{CH}_{3}\right), 22.6\left(\mathrm{CH}_{2}\right), 26.1\left(\mathrm{CH}_{2}\right), 28.9\left(\mathrm{CH}_{2}\right), 29.1$ $\left(\mathrm{CH}_{2}\right), 29.2\left(\mathrm{CH}_{2}\right), 30.3\left(\mathrm{CH}_{2}\right), 31.7\left(\mathrm{CH}_{2}\right), 66.1\left(\mathrm{CH}_{2}\right), 136.8(\mathrm{CH})$, $136.9(\mathrm{CH}), 149.9(\mathrm{CH}), 154.3(\mathrm{CH})$.

\section{Experimental details}

The non-hydrogen atoms were refined with anisotropic thermal parameters. Hydrogen atoms were included in idealised positions and their $U_{\text {iso }}$ values were set to ride on the parent carbon atoms. In the final difference map, the highest peaks (to $c a 0.6 \mathrm{e} \AA^{-3}$ ) were close to the iodide ion.

Scattering factors for neutral atoms were taken from 'International Tables' [7]. Computer programs used in this
This work is licensed under the Creative Commons Attribution 4.0 Brought to you by | University of East Anglia Authenticated 
Table 2: Fractional atomic coordinates and isotropic or equivalent isotropic displacement parameters $\left(\AA^{2}\right)$.

\begin{tabular}{|c|c|c|c|c|}
\hline Atom & $x$ & $y$ & $z$ & $\boldsymbol{U}_{\text {iso }} * / \boldsymbol{U}_{\mathrm{eq}}$ \\
\hline I & $0.11316(6)$ & $0.74147(3)$ & $0.42796(2)$ & $0.06645(16)$ \\
\hline N1 & $0.3798(7)$ & $0.6652(4)$ & $0.6368(2)$ & $0.0559(10)$ \\
\hline $\mathrm{N} 2$ & $0.2229(7)$ & $0.7671(4)$ & $0.6679(3)$ & $0.0639(11)$ \\
\hline C3 & $0.2714(10)$ & $0.9060(6)$ & $0.6580(3)$ & $0.0751(15)$ \\
\hline H3 & 0.1651 & 0.9803 & 0.6789 & 0.090 * \\
\hline C4 & $0.4726(10)$ & $0.9501(6)$ & $0.6180(3)$ & $0.0725(15)$ \\
\hline $\mathrm{H} 4$ & 0.5005 & 1.0509 & 0.6124 & $0.087^{\star}$ \\
\hline C5 & $0.6252(9)$ & $0.8435(7)$ & $0.5878(3)$ & $0.0702(14)$ \\
\hline H5 & 0.7635 & 0.8676 & 0.5613 & $0.084^{\star}$ \\
\hline C6 & $0.5710(9)$ & $0.6964(6)$ & $0.5972(3)$ & $0.0651(13)$ \\
\hline H6 & 0.6706 & 0.6200 & 0.5754 & $0.078^{\star}$ \\
\hline C11 & $0.3125(10)$ & $0.5107(5)$ & $0.6461(3)$ & $0.0749(15)$ \\
\hline $\mathrm{H} 11 \mathrm{~A}$ & 0.4314 & 0.4441 & 0.6199 & $0.090^{*}$ \\
\hline $\mathrm{H} 11 \mathrm{~B}$ & 0.1618 & 0.5119 & 0.6180 & $0.090^{*}$ \\
\hline C12 & $0.2904(11)$ & $0.4490(7)$ & $0.7349(4)$ & $0.0850(17)$ \\
\hline $\mathrm{H} 12 \mathrm{~A}$ & 0.2360 & 0.3502 & 0.7376 & $0.102^{\star}$ \\
\hline $\mathrm{H} 12 \mathrm{~B}$ & 0.1708 & 0.5156 & 0.7608 & $0.102^{\star}$ \\
\hline C13 & $0.5189(11)$ & $0.4337(7)$ & $0.7827(4)$ & $0.0915(18)$ \\
\hline $\mathrm{H} 13 \mathrm{~A}$ & 0.5616 & 0.5342 & 0.7864 & $0.110^{*}$ \\
\hline H13B & 0.6436 & 0.3791 & 0.7525 & $0.110^{*}$ \\
\hline C14 & $0.5080(12)$ & $0.3514(8)$ & $0.8698(4)$ & $0.101(2)$ \\
\hline $\mathrm{H} 14 \mathrm{~A}$ & 0.3866 & 0.4074 & 0.9007 & $0.121^{*}$ \\
\hline H14B & 0.4616 & 0.2516 & 0.8664 & $0.121^{\star}$ \\
\hline C15 & $0.7394(13)$ & $0.3337(8)$ & $0.9156(4)$ & $0.111(2)$ \\
\hline $\mathrm{H} 15 \mathrm{~A}$ & 0.7811 & 0.4338 & 0.9214 & $0.133^{*}$ \\
\hline H15B & 0.8623 & 0.2830 & 0.8829 & $0.133^{\star}$ \\
\hline C16 & $0.7371(13)$ & $0.2453(9)$ & $1.0001(4)$ & $0.115(2)$ \\
\hline $\mathrm{H} 16 \mathrm{~A}$ & 0.6902 & 0.1465 & 0.9945 & $0.138^{\star}$ \\
\hline H16B & 0.6183 & 0.2979 & 1.0335 & $0.138^{\star}$ \\
\hline C17 & $0.9766(14)$ & $0.2234(9)$ & $1.0449(4)$ & $0.120(2)$ \\
\hline $\mathrm{H} 17 \mathrm{~A}$ & 1.0963 & 0.1747 & 1.0103 & $0.144^{\star}$ \\
\hline H17B & 1.0201 & 0.3224 & 1.0522 & $0.144^{\star}$ \\
\hline C18 & $0.9802(14)$ & $0.1309(11)$ & $1.1273(4)$ & $0.140(3)$ \\
\hline $\mathrm{H} 18 \mathrm{~A}$ & 0.9368 & 0.0319 & 1.1200 & $0.168^{\star}$ \\
\hline $\mathrm{H} 18 \mathrm{~B}$ & 0.8604 & 0.1795 & 1.1619 & $0.168^{\star}$ \\
\hline C19 & $1.2147(15)$ & $0.1097(11)$ & $1.1712(5)$ & $0.159(4)$ \\
\hline $\mathrm{H} 19 \mathrm{~A}$ & 1.2032 & 0.0494 & 1.2234 & $0.238^{\star}$ \\
\hline H19B & 1.3340 & 0.0591 & 1.1382 & $0.238^{*}$ \\
\hline H19C & 1.2575 & 0.2069 & 1.1801 & $0.238^{\star}$ \\
\hline
\end{tabular}

analysis have been noted above, and were run through WinGX [4] on a Dell Optiplex 780 PC at the University of East Anglia.

\section{Comment}

In recent decades, ionic liquids (ILs) appeared as an emerging class of ecofriendly compounds alternative to volatile organic compounds (VOCs) due to their outstanding physical and chemical properties such as negligible vapor pressure, excellent thermal and chemical stability, outstanding dissolving capacity, excellent ionic conductivity, non-flammability, and recyclability [8].
These characteristics make ILs strongly attractive for applications in a myriad different fields and these compounds have, therefore, been investigated for a broad range of applications including as potential corrosion inhibitors [9], as liquid crystals [10], in separation technology [11], in electrochemistry [12, 13], in pharmacology [14], and bio-catalysis [15].

The synthesis of the title IL took place through the nucleophilic attack of the $s p^{2}$-nitrogen pyridazine atom, which acts as a nucleophile in the nucleophilic displacement of halogen on the nonyl iodide to afford the corresponding 1-nonylpyridazin-1-ium iodide in $75 \%$ yield as solid material.

The structure of this newly synthesized IL was confirmed by ${ }^{1} \mathrm{H}$-NMR, ${ }^{13} \mathrm{C}$-NMR, single-crystal X-ray diffraction methods and elemental analysis. The ${ }^{1} \mathrm{H}$-NMR spectrum showed a triplet around $\delta \mathrm{H} 0.85$ p.p.m. corresponding to three protons of the methyl group $\left(\mathrm{CH}_{3}\right)$. The protons of the various methylene groups $\left(\mathrm{CH}_{2}\right)$ were observed at their usual chemical shifts. The signals of the pyridazinium protons appeared as two doublets and two triplets, respectively, around $\delta \mathrm{H} 8$ and 9 p.p.m.. The ${ }^{13} \mathrm{C}$-NMR spectrum showed $\mathrm{CH}_{2}$ and $\mathrm{CH}_{3}$ at their usual chemical shifts, and all the aromatic carbons and $\mathrm{C}=\mathrm{N}$ gave the signals between $\delta \mathrm{C} 136-154$ p.p.m.

There are many similarities between this nonyl derivative and the smaller heptyl compound recently reported [16]. The two structure are essentially isostructural even though a different choice of the unit cell is reported. The nonyl group, too, has an all-trans arrangement and is aligned about $\mathrm{C}(11)$ with a cis $\mathrm{N}(2)-\mathrm{N}(1)-\mathrm{C}(11)-\mathrm{C}(12)$ torsion angle of $-61.4(6)^{\circ}$; the $\mathrm{N}(2)-\mathrm{N}(1)-\mathrm{C}(11)-\mathrm{H}(11 a)$ angle is trans at $177.5^{\circ}$. The iodide ion lies over the pyridazinium ring, $3.688 \AA$ from N(1). There are five short $\mathrm{H} \cdots \mathrm{I}$ contacts in the range $3.03-3.14 \AA$, to neighboring cations, forming weak $\mathrm{C}-\mathrm{H} \cdots$. I hydrogen bonds. All the short inter-ion distances involve the iodide ion. As observed for the heptyl structure, the long alkyl chains are arranged in parallel/antiparallel stacks.

Acknowledgements: Musa A. Said thanks the Alexander von Humboldt foundation for the valuable and continuous support.

\section{References}

1. Oxford Diffraction: CrysAlis PRO. Oxford Diffraction Ltd., Oxford, UK (2014).

2. Sheldrick, G. M.: SHELXT - integrated space-group and crystalstructure determination. Acta Crystallogr. A71 (2015) 3-8.

3. Sheldrick, G. M.: Crystal structure refinement with SHELXL. Acta Crystallogr. C71 (2015) 3-8.

4. Farrugia, L. J.: WinGX and ORTEP for Windows : an update. J. Appl. Crystallogr. 45 (2012) 849-854. 
5. Messali, M.; Aouad, M. R.; Ali, A. A.-S.; Rezki, N.; Ben Hadda, T.; Hammouti, B.: Synthesis, characterization, and POM analysis of novel bioactive imidazolium-based ionic liquids. Med. Chem. Res. 24 (2015) 1387-1395.

6. Messali, M.: Eco-friendly synthesis of a new class of pyridinium-based ionic liquids with attractive antimicrobial activity. Molecules 20 (2015) 14936-14949.

7. Prince, E. (Ed.): International tables for crystallography, Vol. C. The International Union of Crystallography, Kluwer Academic Publishers (1992).

8. Earle, M. J.; Esperança, J. M. S. S.; Gilea, M. A.; Canongia Lopes, J. N.; Rebelo, L. P. N.; Magee, J. W.; Seddon, K. R.; Widegren, J. A.: The distillation and volatility of ionic liquids. Nature 439 (2006) 831-834.

9. Lgaz, H.; Benali, O.; Salghi, R.; Jodeh, S.; Larouj, M.; Hamed, O.; Messali, M.; Samhan, S.; Zougagh, M.; Oudda, H.: Pyridinium derivatives as corrosion inhibitors for mild steel in $1 \mathrm{M}$ $\mathrm{HCl}$ : electrochemical, surface and quantum chemical studies. Der Pharma Chem. 8 (2016) 172-190.

10. Levillain, J.; Dubant, G.; Abrunhosa, I.; Gulea, M.; Gaumont, A.-C.: Synthesis and properties of thiazoline based ionic liquids derived from the chiral pool. Chem. Commun. 0 (2003) 2914-2915.

11. Qiu, H.; Jiang, S.; Liu, X.; Zhao, L.: Novel imidazolium stationary phase for high-performance liquid chromatography. J. Chromatogr. A. 1116 (2006) 46-50.

12. Armand, M.; Endres, F.; MacFarlane, D. R.; Ohno, H.; Scrosati, B.: Ionic-liquid materials for the electrochemical challenges of the future. Nat. Mater. 8 (2009) 621-629.

13. Al-Ghamdi, A. F.; Messali, M.; Ahmed, S. A.: Electrochemical studies of new pyridazinium-based ionic liquid and its determination in different detergents. J. Mater. Environ. Sci. 2 (2011) 215-224.

14. Smiglak, M.; Pringle, J. M.; Lu, X.; Han, L.; Zhang, S.; Gao, H.; MacFarlane, D. R.; Rogers, R. D.: Ionic liquids for energy, materials, and medicine. Chem. Commun. 50 (2014) 9228-9250.

15. Sheldon, R. A.: Biocatalysis and biomass conversion in alternative reaction media. Chem. Eur. J. 22 (2016) $12984-12999$.

16. Said, M. A.; Aouad, M. R.; Almutairi, S. M.; Hughes, D. L.; Messali, M.: Crystal structure of 1-heptylpyridazin-1-ium iodide, $\mathrm{C}_{11} \mathrm{H}_{19} \mathrm{~N}_{2}$ I. Z. Kristallogr. NCS 233 (2018) 739-741. 